\title{
The Coercive Function of Early Medieval English Art
}

\author{
Luke A. Fidler
}

A fragment of carved limestone from the Old Minster at Winchester shows a prone
captive with a cord around his neck, looped through his right hand, while a wolf licks
his face (fig. 1). ${ }^{1}$ Although an armed, mailed soldier strides away from the figure, the
surviving surface of the frieze strongly suggests that the cord would have been
staked into the ground rather than held by a captor. If the scene's iconographic
meaning is opaque-indeed, perhaps intentionally ambiguous-it is clear that the
tethered figure formed a striking component of what would have been a large nar-
rative frieze designed for inspection by the public. ${ }^{2}$ The sculptor has counted on this
audience and calculated accordingly, for the recumbent figure's hand is turned out-
ward, as if presenting the rope for inspection, and a slight groove running around the
figures helps them to stand out crisply from the ground. Displayed in one of the most
prominent ecclesiastical institutions of the English world, probably installed on a
wall that would have been visually accessible to people of many different social sta-
tuses, this relief forcefully brings captivity, imprisonment, and torture into the space
of the spectator. But what did it mean for a large stone sculpture to depict captivity
and punishment so publicly when, during the early Middle Ages, England had noth-
ing like a modern police force or prison system?
Without the resources to impose public order through state-sanctioned coer-
cive institutions, the early medieval elite had to regulate public space with strategies
that look remarkably different from those employed in societies accustomed to

Radical History Review

Issue 137 (May 2020) DOI 10.1215/01636545-8092762

(C) 2020 by MARHO: The Radical Historians' Organization, Inc. 


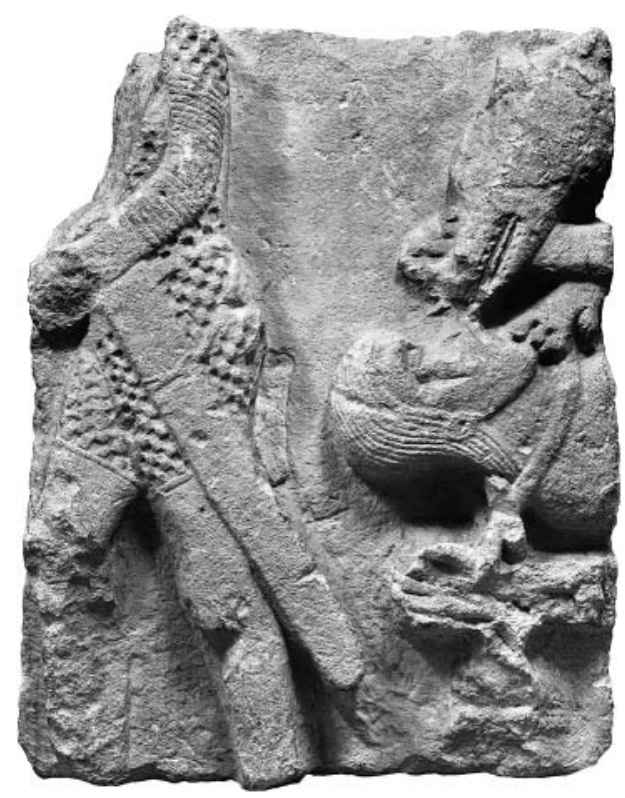

Figure 1. Detail of a bound figure from a narrative frieze (ca. 1017-35 CE). Limestone, $69.5 \times 52 \times 27 \mathrm{~cm}$. Winchester City Museum, no. 2943 WS 98. Photograph (C) Dr. John Crook/ Winchester Excavations Committee.

police rule. Significantly, they tried to do so through works of art that called spectatorial attention to an elaborate, visually striking world of carceral punishment. Querying what, precisely, it meant to populate a landscape with monumental depictions of confinement that looked so much unlike conditions of punishment on the ground, I argue in this essay that public sculpture served a kind of policing function before police, a carceral function before widespread incarceration. ${ }^{3}$ Patrons hungrily marshaled artists' skills so as to keep order in the medieval public sphere. Bearing in mind the degree to which our behavior is policed today by signs, surveillance cameras, walls, posters, and commercials, this particular episode of art history provides an especially useful way to think about punitive regulation in premodern societies, as well as about how discursive objects exercise power over beholding subjects. ${ }^{4}$ Sculptures, argues Richard Neer, "address, imply, or implicate their beholders" and, correspondingly, try to produce effects that manipulate viewers. ${ }^{5}$ The monumental stone sculptures I will discuss dramatically staged scenes of incarceration and escape in order to exert some regulatory control over viewers who saw them in public, often accompanied by forms of verbal address like sermons.

I have chosen to treat early medieval England because it offers a case study of a time and place before the widespread routinization of incarceration in the midthirteenth century, accompanied by the building of special structures for holding captives in the urban environs of Western Europe. A "prison" was more often than not a temporarily converted room that usually served some other functiona storeroom, cellar, or bedroom-meaning that, in the absence of a strong state, ordinary people had to participate in a host of carceral, punitive, and regulatory 
behaviors, surveilling and tracking down their fugitive neighbors and essentially allowing the state to appropriate their spaces of residence and commerce. Art historians have yet to address the ways that the rich corpus of early English public sculpture, which so often visualized a world of captivity and punishment, might have worked to shore up forms of authority in a milieu of distributed policing responsibility.

The term public sculpture in this period does not name anything like art's position as a discursive feature of the bourgeois public sphere outlined by Jürgen Habermas and explored in the art historical context by Thomas Crow. ${ }^{6}$ Viewers did not gather to produce art criticism like eighteenth-century Parisians any more than they were arrested and imprisoned like modern citizens. But viewers did gather to receive knowledge and instruction in public, to hear judgments pronounced and see justice dispensed, to witness military victories celebrated and religious figures venerated. Significantly, they did so in the presence of "marvelous objects wonderfully carved," as large public sculptures are described in the Old English poem Andreas. ${ }^{7}$ These sculptures were not "public" just because they were available to be seen by the multitude but also because they tried to regulate a public discourse about punishment and in this way to govern human behavior.

\section{Incarceration in Early Medieval England}

Punitive incarceration was rare throughout the early medieval period. Rather than serving a punishing function, incarceration tended to be voluntary, rehabilitative (pro amendare), coercive, or custodial, and early English legal codes generally prescribed imprisonment only for debtors or those temporarily awaiting justice. ${ }^{8}$ No archaeological excavation has conclusively identified a single prison from this period, and it seems clear that whatever lawmakers and poets had in mind when they used Old English terms like carcern (prison), they did not refer to an infrastructure of specialized carceral spaces. Instead, the mechanisms of early English justice privileged forms of policing and punishment that only selectively deployed material confinement of any sort. ${ }^{9}$ In the tenth century, for example, King Edward the Elder issued a legal code at Exeter that included provisions for when a gerefa (reeve), a representative of the king who was required to "pronounce legal decisions . . . in accordance with the written laws," did not correctly exact fines. Witnesses assigned to the reeve should hold him accountable and impose, in turn, a fine of 120 shillings payable to the king. ${ }^{10}$ This is a typical kind of early medieval juridical interaction, in which money changed hands, community members outnumbered official representatives, and confinement played no role. On balance, legal codes and lawsuits suggest a world in which issues of compensation and retribution took precedence and where elites and communities alike meted out justice through fines, forfeitures, and physical violence rather than prison terms. 
Sanctioned representatives of the state might collect payments, hear suits, render legal decisions, and carry out some arrests, but communities often had to police themselves. Later custumals, like the thirteenth-century German Sachsenspiegel, describe a class of Schöffen (judges) but repeatedly remind the reader that local people had to help apprehend criminals when the "hue and cry" was raised.11 Although early English legal codes attest specialized positions like the reeve, the daily business of carrying out the law required medieval people to carry out multiple roles as accusers, enforcers, warrantors, and witnesses. In the absence of a police force, many people would have known what it meant to punish as well as to suffer.

Given this fact, it is ideologically significant that verbal and visual representations of justice frame out so many actors. In Abbo of Fleury's tenth-century account of the miracles performed by St. Edmund, he describes how the dead saint bound fast a group of thieves who tried to rob his shrine. ${ }^{12}$ This saintly mystification of who might actually do the work of capturing and fettering is typical of early medieval texts, which are deliberately vague about the specific agents who carry out the business of constraining people and applying violence. ${ }^{13}$ Viewers would have had to infer that the armored warrior on the Winchester panel described earlier was the one responsible for tethering his captive in place, for example. Compounding the issue, early medieval people recognized a certain power in entering relationships of subjection and selectively giving up their own freedom, as practices of self-sale and oblation show. ${ }^{14}$

These absences - of punitive incarceration in early English society and of policing people in early English representations_-are striking because period writers drew on a rich lexicon of confinement. The late antique philosopher Boethius (d. 524) begins his seminal De consolatione philosophiae (The Consolation of Philosophy) by describing himself as "prostate, his mind bowed down / by heavy chains that hang from his neck."15 This image names something of the poem's conditions of production, and it is more than metaphorical, for Boethius wrote it during a year's imprisonment before his execution by the Ostrogothic king Theodoric (d. 526).16 The image of Boethius in chains, visited by a personification of Philosophy, would become a recurrent feature of medieval art and thought. But the Latin text sketches the author's predicament loosely, using the language of imprisonment impressionistically rather than literally, as when the body is referred to as the "earthly prison" of the mind. ${ }^{17}$ It took the translation of Boethius's treatise into Old English for this carceral image to become concrete: "He [Theodoric] commanded/ him to be locked in a prison cell," runs the new version. 18 (This form of elite incarceration would have looked familiar to early medieval readers, for kings commonly confined important prisoners who might fetch ransoms or who were too important to be simply mutilated or killed.) Indeed, English translators also introduced more explicit references to prisons when turning the Latin Soliloquies of St. Augustine into Old English. ${ }^{19}$ If 


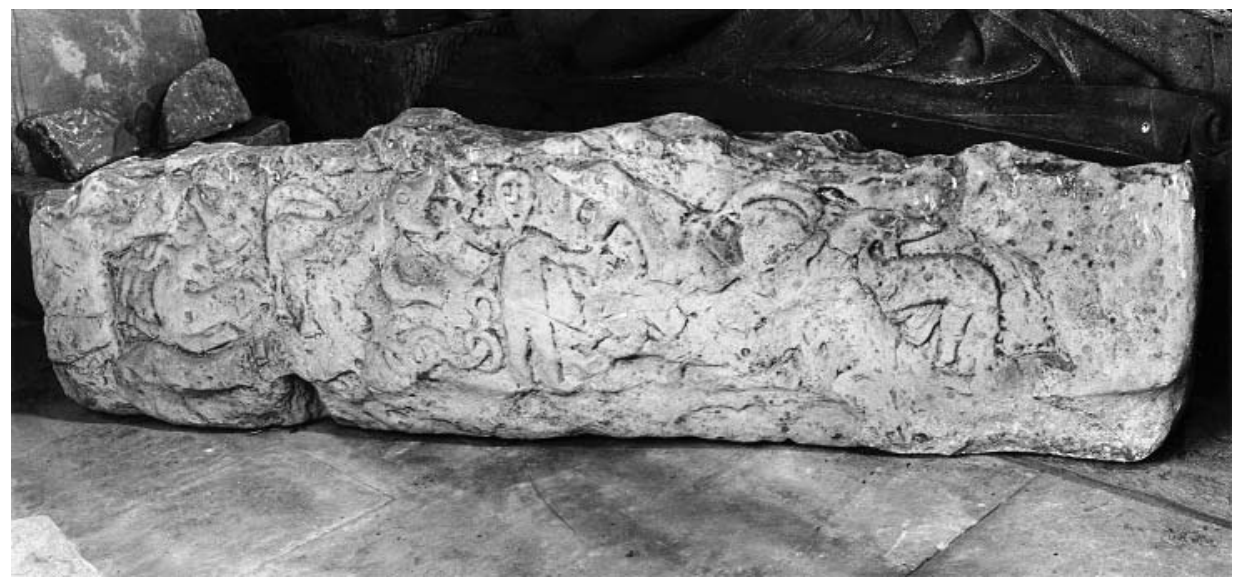

Figure 2. Hogback probably depicting Daniel in the lions' den (ca. 875-915 CE). Medium-grained yellow sandstone, $112.2 \times 24 \times 45.7 \mathrm{~cm}$. Conyers Chapel in All Saints, Sockburn, County Durham. Photograph (C) Corpus of Anglo-Saxon Stone Sculpture, photographer T. Middlemass.

the precise words (variations on carcern such as in or on carcerne) derived from Latin (the noun carcer), the desire to figure confinement as such seems to have emerged in response to particular conditions of English social life. ${ }^{20}$

But what of the sculpted images referencing episodes of captivity and representing bound figures that dotted the landscape? The poetic interest in incarceration provides a useful analog for these sculptures, which not only present powerful visions of confinement but also seem geared to solicit responses from early medieval spectators on the order of homilies, sermons, and other verbal productions meant for public consumption and imaginative engagement. Texts and images worked together in this period, mutually contextualizing each other. Poems help explain why this visual culture flourished while purpose-built prisons were vanishingly rare in the early medieval world. They also show how art served as a mechanism of social control.

\section{Imaging Confinement}

The monumental art of early medieval England consists of carved stones, many adorned with iconographic references to Christian and Germanic texts that feature imprisoned protagonists. One of the elaborately decorated tenth-century sandstone hogbacks from Sockburn, County Durham, which likely served as a grave cover, seems to show the legend of Daniel in the lions' den (Daniel 6:16-23) (fig. 2). ${ }^{21} \mathrm{~A}$ frieze carved in low relief decorates each of the monument's long faces, and each scene centers on a male figure who stands, arms outstretched, amid predatory beasts. The identification, made by the antiquarian William Henry Knowles, is far from secure, although it is tempting to read the hogback in relation to the long Old 
English poem Daniel, which hums with public punishment, idolatrous sculpture, and spectacular visual signs. ${ }^{22}$ (Daniel, a pliant martyr, stands in stark contrast to another prophet from the Hebrew Bible who was popular in English homilies: Jonah, a decidedly unwilling captive in the belly of a whale. $)^{23}$

Whatever the intended subject matter, the Sockburn hogback would have resonated with a variety of stories about captives who were made exemplary by early English preachers. Ælfric's De falsis diis (On False Gods), later expanded by Wulfstan II, relates the story of Daniel's imprisonment in the lions' den in a homily composed for preachers. ${ }^{24}$ Likewise, Aldhelm's seventh-century list of exemplary virgins in his prose De virginitate (On Virginity) includes the tale of Thecla, "brought in front of the cages of the theatrical arena by the bloody hands of the executioners . . . among the fierce roaring of lions and the ferocious jaws of hungry bears." 25 Of course, in Aldhelm's tale, Thecla is martyred by pagans; in early medieval England, executioners and jailers were likely to be personally known to those against whom they practiced violence, not to mention the fact that all parties were likely, at least ostensibly, to be Christian. This might help explain why "bloody hands" flourished in stories of martyrdom culled from late antiquity yet found scant purchase in descriptions of contemporary justice. But other features of the story, not to mention the sermon's performative context itself, square with the sculptures under discussion.

Some of the images of bound, fettered, and otherwise confined figures on public stone sculptures clearly show crucifixions of Christ or St. Andrew, while others are more ambiguous. ${ }^{26}$ As with the Sockburn hogback, many have been interpreted as showing biblical scenes or episodes from Germanic myth, such as the binding of the Norse god Loki or the captivity of Sigmund from the Völunga Saga. Some rehearse the image of a figure confined by ornamental motifs that transgress the bounds of narrative and genre in a manner familiar from the lavishly illuminated manuscripts of the day. A small figure ensnared by zoomorphic interlace appears at the base of the surviving section of a sandstone cross-shaft from Cumberland (fig. 3). ${ }^{27}$ Long ribbons, some incised for further emphasis, swirl around the man, extending across his arms and waist to secure him in place. While the scene has been interpreted as showing anything from a sinner struggling with serpents in Hell to Christ Triumphant, it literally grounds an impressive, elaborate work of art in the predicament of a bound subject. Erected either inside or just outside St. Luke's Church, this large sculpture would have been one of the most important art objects in the area. Viewers may well have connected the eye-catching prisoner to the stories of exemplary captives like Daniel, of overbearing Roman justice drawn from the New Testament, and of martyrs like Thecla.

Rather than stressing the ecclesiastical context in which these figures often appeared, looming large on monumental crosses, I want to draw attention to their public presentation, for medieval writers left no doubt that monuments marked 
Figure 3. Detail of a cross-shaft depicting a figure bound in interlace (tenth century CE). Sandstone, $144 \times 36.5>31 \times 15>14.5 \mathrm{~cm}$. St. Luke's, Great Clifton, Cumberland. Photograph (C) Corpus of Anglo-Saxon Stone Sculpture, photographer T. Middlemass.

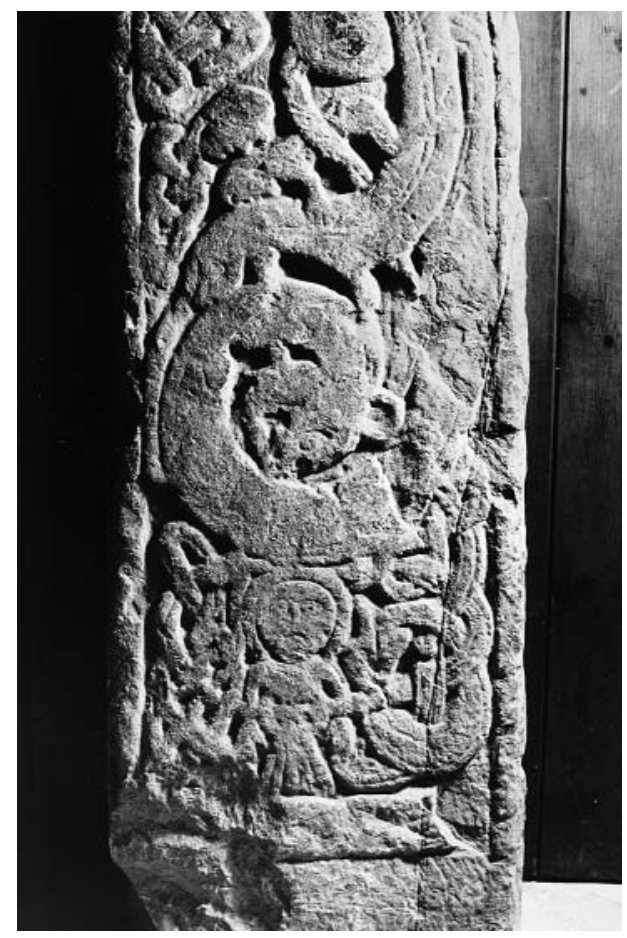

out forms of public space where people gathered. Bede records that monks sang psalms and pilgrims sought miracles at the site of the seventh-century cross ostensibly erected by King Oswald (later St. Oswald) before the battle at Heavenfield (Hefenfeld) in 633 CE. ${ }^{28}$ The ease with which a historic martial site became a religious destination shows how landscapes could acquire overlapping kinds of significance and that monuments erected for one reason might soon take on many meanings. A cross-shaft was never just a religious object, concerned only with devotion. It reinscribed forms of ecclesiastical and social hierarchy and translated religious imagery into a visual language intelligible according to contemporary social concerns. The sculptures I discuss here staged carceral forms by repackaging elements of other kinds of communal encounters with punishment that early medieval people would have known, and this kind of public reiteration transformed violent, juridical encounters into objects of contemplation.

Many viewers would have had to participate in a juridical world where they might have served as witnesses, plaintiffs, or defendants in cases that required violence and subjugation. They would certainly have seen the large, public courts that gathered semiregularly when itinerant officials came to hear suits and dispense justice. Given this familiarity with the world of everyday justice, it is noteworthy that so many public sculptures lavish attention on the material objects deployed in this world, often at the expense of representing the people who carried out the business 
of confining and policing. Shackles, for example, played a key role in the public performance of incarceration, as the fetters and manacles unearthed by archaeologists or those later incorporated into the shrines and portals of continental churches dedicated to saints like St. Foi or St. Leonard poignantly attest. ${ }^{29}$ The Harley Psalter, illuminated in Canterbury during the first half of the eleventh century, depicts two prisoners manacled to columns in a loggia and one with feet in stocks, all three parties abundantly available for the viewer's inspection. ${ }^{30}$ Texts like the Old Irish Crith Gablach describe a royal entourage which includes "forfeited hostages in fetters," underscoring the role that chains played in the public arena as signs of disempowerment. ${ }^{31}$

Moreover, images and texts demonstrate that early medieval spectators were keenly aware of shackles as signifiers with outsize importance, and that they carefully differentiated between types of shackling technology. English vitae of St. Swithun repeatedly describe the saint freeing slaves from shackles. In Lantfred's late tenth-century prose version, the miracle graphically describes the objects used to lock people up: a slave, "bound up in heavy chains for several days," was praying before Swithun's tomb when "suddenly the bolt sprang out of the shackles, and thus these shackles were miraculously released as if someone had undone them with a key."32 In its evocation of weight, bolts, and keys, this passage paints a detailed picture of the material culture of confinement, and Lantfred carefully distinguishes "head-collar" (columbare) from "foot-shackles" (compedes) in his account. In a final example, the twelfth riddle of the Exeter Book ventriloquizes a leather strap: "If life leaves me, I will tightly bind / the dark Welshmen."33 Such pictures of spectacular confinement may have helped accustom viewers to the smaller-scale forms of policing and justice in which they had to participate, the visual emphasis on cords and manacles perhaps masking, and perhaps standing in for, the many kinds of juridical labor that viewers performed during their lives.

Correspondingly, sculptors lavished detail on the mechanisms used to bind their subjects. The so-called Bound Devil Stone, a tenth-century cross-shaft, depicts a horned figure prominently constrained by ring-and-bar bindings on both hands and feet (fig. 4). ${ }^{34}$ Similar shackles have been excavated from a range of sites across Europe. ${ }^{35}$ The deep relief carved around the rings and bars that lock the figure in place draws the gaze to these nodes of concentrated light and shadow, while the thick cord that links them works like a second frame to emphasize the obdurate fact of confinement. Strikingly, this scene-like the bound figure discussed abovewould have originally served as a panel on the face of a large, heavily decorated cross that probably stood outside, available for public inspection and periodically activated by the verbal pronouncements of priests and visitors. This was a picture to be considered in company and, given the rich vocabulary of shackling attested in the literature of the period, it seems likely that the sculptor's careful carving of the figure's manacles and fetters would have been noticed and discussed by viewers; 
Figure 4. Detail of a cross-shaft, known as "The Bound Devil Stone" (tenth century CE). Sandstone, $65 \times 35>32 \times 19>18 \mathrm{~cm}$. St. John's, Kirkby Stephen, Westmorland. Photograph (C) Corpus of Anglo-Saxon Stone Sculpture, photographer T. Middlemass.

after all, Benjamin Saltzman argues that "certain metaphors of servitude_of binding and fettering, of ownership and control" underlay the extremely popular corpus of early medieval riddles. ${ }^{36}$ In a time when labor markets depended on noneconomic coercion, forms of pressure and unfreedom were ever present.

As Richard Neer argues, "The effect of a given work of sculpture-its solicitation and retention of a beholder's attention, its specific modes of appeal, gratification, frustration - is not an incidental or trivial fact about it. On the contrary, a statue's effect is arguably the most important, the essential thing." 37 But how do contemporary scholars come by a sculpture's effects? Early medieval writers left notoriously few written reflections on sculpture, despite their rich descriptions of objects. The Bound Devil Stone, with its arresting, frontal presentation of a confined figure, set off from the ground by narrow passages of deep relief that would have been shadowed throughout the day, also warrants inspection for the ways that it rendered talk about imprisonment convincing. My argument wagers not just that these sculptures show a preoccupation with metaphors of incarceration but that they produced and structured the ways that viewers conceived of incarceration and policing. The sculptor of the Bound Devil Stone marshaled the stone's effects in virtuosic fashion, drawing the viewer's eye to those densely articulated places where chains 
lock the subject's limbs in place, then funneling the gaze in a loop around the circular cord, against the resolutely vertical flow of the figure and the larger cross itself. Confinement is no mere iconographic feature. It structures the composition, manipulates the beholder, and constrains whatever interpretation an inquisitive viewer might coin.

All the evidence we do have for the way that early medieval viewers interpreted stone sculpture suggests that they marveled over how sculptors teased threedimensional forms from stone. These forms had a special kind of liveliness. Writing just after the Norman Conquest, Goscelin of St. Bertin describes some carvings as "wonderfully formed." 38 Similarly, in the Old English Andreas, St. Andrew describes Christ preaching in vain in the temple, the sinful unable to see the "signs" (tacna) of his speech. ${ }^{39}$ Noticing the "marvelous objects wonderfully carved, images of his angels . . . splendidly adorned, beautifully made" on the temple walls, Christ praises their facture then commands one of the sculptures to leap down and speak to the audience. 40 The work, "stone from stone" (stan fram stane), reprimands the priests and instructs the crowd, before Christ directs it to wander the world preaching and resurrecting the patriarchs. ${ }^{41}$ Setting aside the intriguing fact that the poet depicts preaching taking place before figural sculpture, it is noteworthy that, like Goscelin, the author of Andreas stresses the stone's wonderful workmanship. The sculpture is wonderful even before it becomes miraculously animated, and Christ's command simply activates its latent exhortatory, publicly persuasive function. Here, both Goscelin and the author of Andreas share the medieval sense of wonder (admiratio), which opposed the exceptional, the rare, and the skillfully crafted to those things belonging to the category of the usual (solitum). ${ }^{42}$ Small wonder, then, that the Bound Devil Stone's pronounced contrast between foreground and background and its concentration of chiseled detail around manacles drew attention to those tricky areas of carving that demonstrated skilled craftsmanship. Here, the accoutrements of confinement took on a disproportionate liveliness and threatened to erupt into the spectator's space, effectively empowering the sculpture to exert control over its viewers. In the early fifth century, Severian of Gabala argued that statues of the emperor ought to be erected in law courts, markets, and other sites of public assembly, "so that the emperor may thus confirm what takes place." 43 The power of a figural sculpture to censure or sanction behavior recurs in Andreas and the Bound Devil Stone.

Moreover, as art historians have shown, early medieval English sculpturessome inscribed, others not-were broadly understood as discursive objects whose enigmatic pronouncements required interrogation, and some were clearly designed to speak didactically. ${ }^{4}$ The towering eighth-century Ruthwell Cross, for example, bears inscriptions in which the monument speaks in the first person as part of a multimedia program designed to conscript the viewer/reader into a particular vision of ecclesiastical life. ${ }^{45}$ Sculpted figures representing the vita activa and vita 
contemplativa provided models not simply for individual viewers to imitate but for the reconstitution of social life. ${ }^{46}$ As images and texts migrated across media, from oral performance to monumental object and back, they shaped each other's reception as well as form. ${ }^{47}$ If many cultures share a practice of didactic public art, the sculptures of early medieval England uniquely presented agentive, inanimate sculptures, purposefully erected in and around churches where pilgrims and passersby would gather. Key features of the social landscape, they regulated behavior in part by representing norms and rules in the guise of obdurate authority that acquired divine sanction by virtue of their association with the real church institutions that usually housed them. They were implicitly connected to biblical precedents like the brazen serpent erected by Moses as a divinely efficacious sign (Numbers 21:4-9). Rather than expecting early medieval pictures to straightforwardly describe the world, then, we should imagine viewers inspecting patterns, speculatively identifying with sculpted figures, and expecting to receive coded forms of instruction.

Where prisons actually are depicted explicitly (rather than analogically) in early English art, they are usually shown in the context of escape. Moreover, buildings rarely include specific iconographic clues that would identify them as prisons per se, focusing largely on features like bars and heavy doors as well as the shackles confining specific prisoners, in keeping with the fact that early medieval prisons were usually just rooms or buildings temporarily repurposed for limited carceral terms. A number of large and small sculptures depict episodes from the Germanic tale of Weland the Smith, in which he is captured by King Niðhad, hobbled, and put to work forging objects for the king. ${ }^{48}$ He appears at the beginning of Deor, a lament preserved in the tenth-century Exeter Book that poetically compresses his fetters and severed hamstrings by describing him as constrained with "supple sinew-bonds" (swoncre seonobende). ${ }^{49}$ Thus Weland represents a rare intersection of multiple categories of early medieval incarceration: captivity, confinement, forced labor, and bodily mutilation. While Weland's most famous appearance in English art focuses on his work at the forge (appearing on the eighth-century Franks Casket), sculptors tend to depict his miraculous escape by means of artificial flight when it comes to large-scale monuments. ${ }^{50}$ As described in the West Norse Piðrekssaga, the written form of which postdates the sculpture but preserves earlier oral formulations, Weland's brother collected feathers that the captive smith crafted into a flying machine or suit in order to fly like a bird.51

A fragment from a sandstone cross-shaft, carved sometime between the late ninth and early tenth century, shows the smith with what appear to be fetters on his legs and the arc of a bird's wingspan framing his upper body, hands tightly gripping his engine of flight (fig. 5).52 Other depictions look far more like the Daedalus legend-perhaps misleadingly so-as in a contemporaneous carved fragment from York in which Weland appears with outstretched wings, the feathers strapped to his arms. ${ }^{53}$ Again, artists chose to depict Weland's confinement and escape rather 


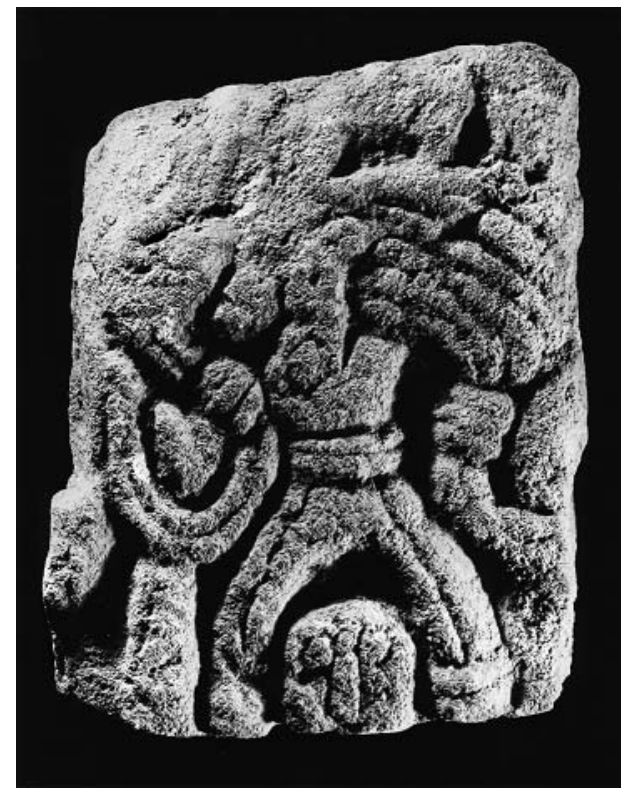

Figure 5. Fragment of a cross-shaft depicting Weland's escape (late ninth to early tenth century CE). Coarse-grained sandstone, $27.6 \times 22.6 \times 17.5 \mathrm{~cm}$. St. Hilda's, Sherburn, East Yorkshire. Photograph (c) Corpus of Anglo-Saxon Stone Sculpture, photographer T. Middlemass.

than his capture, displacing the labor of incarceration into objects like fetters. If large stone crosses could present spectacularly confined figures to the public, they could also show legendary characters fleeing conditions of captivity and penal enslavement in ways that certainly do not square with the fiercely regulated worlds of contemporaneous slave labor. 54 Scholars have argued that the scenes show Weland as a Christian type, describing the cross scene as "a swiftly comprehensible image of redemption, of the deliverance of a soul." Policing the social world meant marshaling both Christian and non-Christian resources to construct a plausible discourse of incarceration and escape. 55

\section{Conclusion}

If early medieval sculptures, made in stone during the ninth through the eleventh centuries, had a profoundly limited carceral landscape of prisons to respond to, they demonstrated a clear interest in figuring forms of imprisonment that attended carefully to the period interest in delineating material techniques of confinement. Manacles and cords are some of the most precisely rendered details of these sculptures, corresponding to a textual discourse of head-collars, double chains, and fetters, and a real-world set of tools that spectators would have known intimately through their participation in the everyday business of juridical labor. Crucially, these sculptures were displayed in public, as part of a set of creative works, including homilies, poems, and sermons, that asked early medieval subjects to imagine states of confinement. Sermons are of special interest, since we know that they were intended to be preached in public and would thereby have formed an interpretive 
context for sculpted cross-shafts that were often erected close to, if outside, churches. ${ }^{56}$ The first of the Old English Napier "homilies" reprises and fleshes out an analogy drawn from the Dialogi (Dialogues) of Gregory the Great, comparing earthly life to the experience of a fictive prisoner who has come of age while incarcerated, disinclined to believe his mother's stories about fields, fish, and stars beyond the prison walls. ${ }^{57}$ Indeed, the story of Weland repeatedly asked listeners, readers, and viewers to speculate about conditions of captivity that did not correspond to English social conditions. Large, compelling sculptures tried to do the same.

This case study tells us something significant about the long relationship between art and policing. Early medieval public sculpture "policed" viewers in two ways. First, by using a straightforward technique of displacement, artists cultivated an iconography of confinement that elided the labor of witnessing, capturing, judging, and punishing potential wrongdoers. Drawing on the carving techniques peculiar to relief sculpture, as well as a period discourse about sculptural liveliness, they deflected anxiety about what it meant to participate in punitive systems. Reifying the material culture of justice, showing manacles rather than jailers, they functionally sidestepped the question of who (or what) authorized subjection. Second, acknowledging the logistical limits of state surveillance, these sculptures were meant to serve as surrogate enforcers of order. After all, if works of art can compel, constrain, and persuade their beholders, then it stands to reason that coercive states will seek to exploit those properties. From Johannes Gelert's oft-targeted statue of a Chicago policeman erected in Haymarket Square in 1889 (now barricaded from public access at the Chicago Police Department's headquarters) to the mosaic murals decorating the Pyongyang metro system, authorities have used art to manipulate public space. 58 The Bound Devil Stone and the Weland crosses show that early medieval England was also subjected to a visual culture of control, albeit one that drew on period notions about wondrously carved relief sculpture rather than the socialist realism of North Korean tesserae.

As Celia Martin Chazelle points out, the medieval past offers a concrete example of a society that did without widespread policing and punitive confinement. ${ }^{59}$ By turning to its art, I do not mean to suggest that the Middle Ages, particularly the slave-holding world of the early medieval period, offers an ideal model on which to found an abolitionist future. ${ }^{60}$ Rather, by inspecting how a group of artworks tried to enact forms of coercion and consensus, specifically by invoking the specter of confinement in early medieval England, I have taken stock of a particular counterfactual drawn from a past when people developed mechanisms of justice without recourse to mass incarceration or agents of the state charged with coercive violence. In this world, art conspicuously helped to produce a discourse of control.

Luke A. Fidler is a doctoral candidate in the Department of Art History at the University of Chicago. 


\section{Notes}

I am extremely grateful to Jack Dragu, Tamara Golan, Aden Kumler, Jason D. LaFountain, Chloé M. Pelletier, and Benjamin Saltzman for their help with this essay. The editors, especially Amy Chazkel, provided many invaluable suggestions. An earlier draft was presented at the University of Chicago Medieval Studies Workshop. This essay is dedicated to my students in "Art and Empire in the Ancient World" at Stateville Correctional Center.

1. See, with bibliography, "Winchester (Old Minster) 88," in The Corpus of Stone AngloSaxon Sculpture, www.ascorpus.ac.uk/catvol4.php?pageNum_urls=277 (accessed November 23, 2019).

2. Karkov, "The Wolves of Winchester." Thanks to Catherine Karkov for sharing her unpublished paper with me.

3. Although medieval incarceration remains understudied, an important body of historiographical literature does exist, primarily in German: Bohne, Die Freiheitsstrafe in den italienischen Stadtrechten des 12.-16. Jahrhunderts; Krauss, Im Kerker vor und nach Christus; Hippel, Strafrechtsreform und Strafzwecke. For an overview, see Peters, "Prison before the Prison."

4. For art as an agentive force, see the influential account in Gell, Art and Agency. Although widely cited by medievalists, his argument has serious shortcomings and does not map smoothly onto medieval objects. Art historians have typically framed medieval art's didactic mission in terms of the Gregorian dictum to instruct the illiterate; Duggan, "Was Art Really the 'Book of the Illiterate?'”

5. Neer, The Emergence of the Classical Style, 12.

6. Crow, Painters and Public Life; Habermas, Strukturwandel der Öffentlichkeit.

7. "Wrætlice wundor agræfene ... wlitige geworhte." "Andreas," in Old English Poems of Christ and His Saints, 231 (line 712). My argument is indebted to previous studies of medieval punishment and public violence, including Decker and Kirkland-Ives, Death, Torture and the Broken Body in European Art; Geltner, Flogging Others; Groebner, Ungestalten; Merback, The Thief, the Cross, and the Wheel.

8. Many of the relevant legal codes are edited and translated in Attenborough, The Laws of the Earliest English Kings.

9. Rio, Slavery after Rome. Important discussions of shifting attitudes toward incarceration toward the end of the pre-Conquest period include Dunbabin, Captivity and Imprisonment in Medieval Europe; Pugh, Imprisonment in Medieval England.

10. “Deman swa rihte domas . . . 7 hit on ðære dombec stande." See, respectively, I Edward and II Edward \$3.2, in Attenborough, The Laws of the Earliest English Kings, 114 and 119 .

11. For an English translation of one Sachsenspiegel manuscript, see The Saxon Mirror.

12. Winterbottom, Three Lives of English Saints, 83-84.

13. See a ninth-century definition of prison: De carcere: Carcer est, a quo prohibemur exire. Rabanus Maurus, De universo libri, $389 \mathrm{~A}$.

14. O'Brien O'Keeffe, Stealing Obedience.

15. Boethius, The Consolation of Philosophy, 5. For Boethius's influence on late medieval incarcerated writers, see Summers, Late-Medieval Prison Writing, 16-17. For a useful introduction to Boethius's life and thought, see Gruber, Boethius.

16. For the political context of Boethius's plight, see Barnish, "Maximian, Cassiodorus, Boethius, Theodahad."

17. Boethius, The Consolation of Philosophy, 55 . 
18. "He hinne inne heht / on carcerenes cluster belucan." Boethius, The Old English Boethius, 73. For more on this translation, which was long ascribed to King Alfred (d. 899), see Discenza, The King's English. For the impact of De consolatione on early English thought, see Szarmach, "Boethius's Influence in Anglo-Saxon England."

19. Thomas, "Incarceration as Judicial Punishment in Anglo-Saxon England," 92-93. For the original source, see Carnicelli, King Alfred's Version of St. Augustine’s Soliloquies, 96.

20. Cameron et al., Dictionary of Old English. See also Thomas, "Incarceration as Judicial Punishment in Anglo-Saxon England," 93n5. Lori Garner argues that the metaphorical images of locks and walls, exemplified by the increasingly wide semantic field of the term clustorcleofan (locked cell), came to acquire a broad range of emotional meanings as well as specifying literal forms of confinement. Garner, Structuring Spaces, 76-77. See also Cavell, Weaving Words and Binding Bodies; Saltzman, Bonds of Secrecy, 161-83. Thanks to Ben Saltzman for sharing his forthcoming manuscript with me.

21. "Hogback" usually refers to recumbent grave markers produced during the tenth and eleventh centuries. From a larger bibliography, see Bailey, Viking Age Sculpture in Northern England; Lang, "The Hogback"; Williams, "Hogbacks.” As such, the Sockburn hogback would have conjured notions of the grave as a custodial, rehabilitative site, related to the long history of representing prophets like Daniel and Jonah or late antique sarcophagi.

22. Knowles, "Sockburn Church," 116. See, with bibliography, "Sockburn 21," in The Corpus of Anglo-Saxon Stone Sculpture, www.ascorpus.ac.uk/corpus_vol1.php?pageNum_ urls $=487 \&$ totalRows_urls $=532$. The figure might be drawn from a non-Christian iconography; more to the point, early medieval English viewers seemed to have expected, and perhaps enjoyed, polysemic images. See Karkov, The Art of Anglo-Saxon England; Tilghman, "On the Enigmatic Nature of Things in Anglo-Saxon Art"; Webster, "Visual Literacy in a Protoliterate Age."

23. Szarmach, "Three Versions of the Jonah Story." Jonah is also depicted in early English art, most notably on the stole of St. Cuthbert.

24. See the discussion in Lees, Tradition and Belief, 66-7o. For more on homilies and preaching, see Clayton, "Homiliaries and Preaching in Anglo-Saxon England"; Huppé and Szarmach, The Old English Homily and Its Backgrounds; Gatch, Preaching and Theology in Anglo-Saxon England; Gatch, "The Unknowable Audience of the Blickling Homilies"; Kleist, The Old English Homily.

25. Aldhelm, the Prose Works, 113.

26. A strong argument is made for the theological source of bondage in Rendall, "Bondage and Freeing from Bondage in Old English Religious Poetry."

27. See, with bibliography, "Great Clifton," in The Corpus of Anglo Saxon Stone Sculpture, www.ascorpus.ac.uk/catvol2.php?pageNum_urls=97. The problem of ornament as confinement warrants further study.

28. Bede, Ecclesiastical History of the English People, III, 2, 214-17. On Oswald's cross, see MacLean, "King Oswald's Wooden Cross at Heavenfield in Context."

29. Shackles have been interpreted as evidence of the early medieval slave trade's range: see Henning, "Gefangenenfesseln im slawischen Siedlungsraum." For a cautionary note, see Fontaine, "Early Medieval Slave-Trading in the Archaeological Record." Mention is made of shackles left at the shrine of St. Foi at Conques in Bernard of Angers's well-known account, and chains may still be seen on display at churches like Notre Dame d'Orcival in Puy-de-Dôme. They are depicted in the sculptural programs of numerous churches dedicated to St. Foi and St. Leonard. 
30. The manuscript largely copies the ninth-century Utrecht Psalter. It is fully digitized in color and available online (see folio 45v), www.bl.uk/manuscripts/FullDisplay.aspx ?ref=Harley_MS_6o3. For a discussion of this scene, see Sexton, "Justice Seen," 313.

31. Translated in MacNeill, "Ancient Irish Law," 305-6.

32. Lantfred, Translatio et miracula S. Swithuni, 333.

33. "Gif me feorh losað, fæste binde / swearte Wealas," "Riddle 12," in Krapp and Dobbie, The Exeter Book, 186 (lines 3-4). The riddles repeatedly refer to Welsh slaves. The Exeter Book riddles have been mined extensively for evidence about early medieval slavery; see, with bibliography, Saltzman, Bonds of Secrecy, 169-75.

34. See, with bibliography, "Kirkby Stephen o1," in The Corpus of Anglo Saxon Stone Sculpture, www.ascorpus.ac.uk/catvol2.php?pageNum_urls=113\&totalRows_urls=181. The figure has been identified with a host of Christian and Norse protagonists, and the curled volutes on the head are not always agreed to be horns.

35. Henning, "Gefangenenfesseln im slawischen Siedlungsraum."

36. Saltzman, Bonds of Secrecy, 161.

37. Neer, The Emergence of the Classical Style, 1.

38. Quoted in Dodwell, Anglo-Saxon Art, 122.

39. Andreas, 230 (line 711). For this passage, see Ramey, "The Riddle of Beauty," 470-71.

40. "Wrætlice wundor agræfene, / anlicnesse engla sinra . . . torhte gefrætwed, / wlitige geworhte." Andreas, 230 (lines 712-16).

41. Andreas, 232 (line 738 ).

42. Bynum, "Wonder," 7. The Old English term used here (wrætlic) specifically refers to something cut or carved; Juzi, "Die Ausdrücke des Schönen."

43. Elsner, Imperial Rome and Christian Triumph, 54 .

44. From a larger bibliography, see Bredehoft, "First-Person Inscriptions and Literacy in Anglo-Saxon England"; Karkov, The Art of Anglo-Saxon England, 135-78; Tilghman, "On the Enigmatic Nature of Things in Anglo-Saxon Art." As such, early medieval England is one of the special cases where people saw art as agentive; it is not easily assimilated to Alfred Gell's general claims about agency that medieval art historians often reference when explaining this historical phenomenon. On this score, I thank Tamara Golan and Richard Neer for their conversations about Gell.

45. The cross has a vast bibliography; for a helpful introduction to the monument, see Karkov, The Art of Anglo-Saxon England, 137-45.

46. Farr, "Worthy Women on the Ruthwell Cross."

47. Chaganti, "Vestigial Signs."

48. Kopár, "Weland the Smith"; Kopár, "The Wings of Weland." Two sources, the piðreks saga and the Völundarkviða, mention Weland's flight. See, respectively, Jónsson, piðreks saga af Bern, and Dronke, The Poetic Edda, 239-328.

49. Deor, in The Exeter Book, 178 (line 6).

50. The Franks Casket may also show the making of the flying machine, but the iconography is ambiguous. Images of airborne escape permeate the Völundarkviða, which opens with the flight of the Valkyries.

51. Jónsson, Piðreks saga af Bern, vol. 1, 112-13. In the Völundarkviða, he simply "lifted himself into the sky" (hófz at lopti) where he is said to "hover" (skollir). Dronke, The Poetic Edda, 251, 253. In contrast to the Piðreks saga, this version strongly suggests that Völundr/Weland possesses the supernatural power of flight. Scholars have convincingly argued that the Piðreks saga derives from earlier English and Germanic material. 
52. See, with bibliography, "Sherburn 3," in The Corpus of Anglo Saxon Stone Sculpture, www.ascorpus.ac.uk/catvol3.php?pageNum_urls=113.

53. See, with bibliography, "York Minster og," in The Corpus of Anglo Saxon Stone Sculpture, www.ascorpus.ac.uk/catvol3.php?pageNum_urls=181.

54. Slavery in early medieval England, and in northern Europe more generally, is a large and complicated topic. For a recent assessment, see Rio, Slavery after Rome.

55. Dronke, The Poetic Edda, 281.

56. For a useful introduction to pre-Conquest sermons, see Cross, "Vernacular Sermons in Old English."

57. The text survives in three versions. Although called homilies, scholars have convincingly argued that the Napier "homilies" were really sermons in the sense that they were designed for a preacher to address an audience about a topic derived from, but not systematically explicating, a sacred text. See Lionarons, The Homiletic Writings of Archbishop Wulfstan, 28-29; Szarmach, "Another Old English Translation of Gregory the Great's Dialogues?"; Thomas, "Rewriting Gregory the Great."

58. Lampert, "Haymarket"; Gabriel, "Revolution from 360 Feet Below."

59. Chazelle, "Crime and Punishment."

6o. The classic study of medieval slavery is Verlinden, L'esclavage dans l'Europe médiévale. For the early medieval period in particular, see Hammer, A Large-Scale Slave Society.

\section{References}

Aldhelm. Aldhelm, The Prose Works, translated by Michael Lapidge and Michael W. Herren. Cambridge: D. S. Brewer, 1979.

Attenborough, F. L., ed. The Laws of the Earliest English Kings. Cambridge: University Press, 1922.

Bailey, Richard N. Viking Age Sculpture in Northern England. London: Collins, 1980.

Barnish, S. J. B. "Maximian, Cassiodorus, Boethius, Theodahad: Literature, Philosophy and Politics in Ostrogothic Italy." Nottingham Medieval Studies 34 (1990): 16-32.

Bede. Bede's Ecclesiastical History of the English People, edited by Bertram Colgrave and R. A. B. Mynors. Oxford: Clarendon Press, 1969.

Boethius. The Consolation of Philosophy, translated by David R. Slavitt. Cambridge, MA: Harvard University Press, 2008.

Boethius. The Old English Boethius: With Verse Prologues and Epilogues Associated with King Alfred, translated by Susan Irvine and Malcolm Godden. Cambridge, MA: Harvard University Press, 2012.

Bohne, Gotthold. Die Freiheitsstrafe in den italienischen Stadtrechten des 12.-16. Jahrhunderts. 2 vols. Leipzig: T. Weicher, 1922.

Bredehoft, Thomas A. "First-Person Inscriptions and Literacy in Anglo-Saxon England." AngloSaxon Studies in Archaeology and History 9 (1996): 103-10.

Bynum, Caroline Walker. “Wonder.” The American Historical Review 102, no. 1 (1997): 1-26.

Cameron, Angus, et al. Dictionary of Old English: A to I. Toronto: Dictionary of Old English Project, 2018.

Carnicelli, Thomas A., ed. King Alfred's Version of St. Augustine's Soliloquies. Cambridge, MA: Harvard University Press, 1969.

Cavell, Megan. Weaving Words and Binding Bodies: The Poetics of Human Experience in Old English Literature. Toronto: University of Toronto Press, 2016. 
Chaganti, Seeta. "Vestigial Signs: Inscription, Performance, and 'The Dream of the Rood." PMLA 125, no. 1 (2010): 48-72.

Chazelle, Celia Martin. "Crime and Punishment: Penalizing without Prisons.” In Why the Middle Ages Matter: Medieval Light on Modern Injustice, edited by Celia Martin Chazelle, Simon Doubleday, Felice Lifshitz, and Amy G. Remensnyder, 15-28. London: Routledge, 2012.

Clayton, Mary. "Homiliaries and Preaching in Anglo-Saxon England." Peritia 4 (1985): 207-42.

Cross, J. E. “Vernacular Sermons in Old English.” In The Sermon, edited by Beverly Mayne Kienzle, 561-96. Turnhout: Brepols, 2000.

Crow, Thomas E. Painters and Public Life in Eighteenth-Century Paris. New Haven, CT: Yale University Press, 1985 .

Decker, John R., and Mitzi Kirkland-Ives, eds. Death, Torture and the Broken Body in European Art, 1300-165o. Farnham, Surrey: Ashgate, 2015.

Discenza, Nicole Guenther. The King's English: Strategies of Translation in the Old English Boethius. Albany: State University of New York Press, 2005.

Dodwell, C. R. Anglo-Saxon Art: A New Perspective. Ithaca, NY: Cornell University Press, 1982.

Dronke, Ursula, trans. The Poetic Edda. Vol. 2, Mythological Poems. Oxford: Clarendon Press, 1997.

Duggan, Lawrence G. "Was Art Really the 'Book of the Illiterate’?” Word \& Image 5, no. 3 (1989): 227-51.

Dunbabin, Jean. Captivity and Imprisonment in Medieval Europe, 10oo-130o. Basingstoke, Hampshire: Palgrave Macmillan, 2002.

Elsner, Jaś. Imperial Rome and Christian Triumph: The Art of the Roman Empire AD 10o-450. New York: Oxford University Press, 1998.

Farr, Carol Ann. "Worthy Women on the Ruthwell Cross: Woman as Sign in Early Anglo-Saxon Monasticism.” In The Insular Tradition, edited by Robert T. Farrell, Catherine E. Karkov, and Michael Ryan, 45-61. Albany: State University of New York Press, 1997.

Fontaine, Janel M. "Early Medieval Slave-Trading in the Archaeological Record: Comparative Methodologies." Early Medieval Europe 25, no. 4 (2017): 466-88.

Gabriel, Douglas. "Revolution from 360 Feet Below: Form and Ideology in the Pyongyang Metro.” Journal of Korean Studies 23, no. 1 (2018): 111-33.

Garner, Lori Ann. Structuring Spaces: Oral Poetics and Architecture in Early Medieval England. Notre Dame, IN: University of Notre Dame Press, 2011.

Gatch, Milton McC. Preaching and Theology in Anglo-Saxon England: Aelfric and Wulfstan. Toronto: University of Toronto Press, 1977.

Gatch, Milton McC. “The Unknowable Audience of the Blickling Homilies.” Anglo-Saxon England 18 (1989): 99-115.

Gell, Alfred. Art and Agency: An Anthropological Theory. Oxford: Clarendon Press, 1998.

Geltner, Guy. Flogging Others: Corporal Punishment and Cultural Identity from Antiquity to the Present. Amsterdam: Amsterdam University Press, 2014.

Groebner, Valentin. Ungestalten: Die visuelle Kultur der Gewalt im Mittelalter. München: Carl Hanser, 2003.

Gruber, Joachim. Boethius: Eine Einführung. Stuttgart: Anton Hiersemann, 2011.

Habermas, Jürgen. Strukturwandel der Öffentlichkeit: Untersuchungen zu einer Kategorie der bürgerlichen Gesellschaft. Neuwied: Luchterhand, 1962.

Hammer, Carl I. A Large-Scale Slave Society of the Early Middle Ages: Slaves and Their Families in Early Medieval Bavaria. Aldershot: Ashgate, 2002. 
Henning, Joachim. "Gefangenenfesseln im slawischen Siedlungsraum und der europäische

Sklavenhandel im 6. bis 12. Jahrhundert: Archäologisches zum Bedeutungswandel von 'sklabos - sakaliba - sclavus.'” Germania 7o (1992): 403-26.

Hippel, Robert von. Strafrechtsreform und Strafzwecke. Göttingen: W. F. Kästner, 1907. Huppé, Bernard Felix, and Paul E. Szarmach, eds. The Old English Homily and Its

Backgrounds. Albany: State University of New York Press, 1978.

Jónsson, Guðni, ed. Piðreks saga af Bern. 2 vols. Reykjavík: Íslendingasagnaútgáfan, 1954.

Juzi, Gertrud. "Die Ausdrücke des Schönen in der altenglischen Dichtung: Untersuchung uber ein sprachliches Feld." PhD diss., Zurich, 1939.

Karkov, Catherine E. The Art of Anglo-Saxon England. Woodbridge, UK: Boydell, 2011.

Karkov, Catherine E. "The Wolves of Winchester." Unpublished paper.

Kleist, Aaron J., ed. The Old English Homily: Precedent, Practice, and Appropriation. Turnhout, Belgium: Brepols, 2007.

Knowles, W. H. “Sockburn Church.” Transactions of the Architectural Society of Durham and Northumberland 5 (1896-1905): 99-120.

Kopár, Lilla. "Weland the Smith: Iconographic and Literary Sources from Anglo-Saxon England." In Proceedings from the 7 th Nordic Conference on English Studies, edited by Sanna-Kaisa Tanskanen and Brita Warvik, 411-20. Anglicana Turkuensia 2o, Addendum. Turku: University of Turku, 1999.

Kopár, Lilla. "The Wings of Weland." In The Iconography of the Fantastic: Eastern and Western Traditions of European Iconography 2, edited by Attila Kiss, Márta Baróti-Gaál, and György E. Szőnyi, 39-48. Szeged: JATEPress, 2002.

Krapp, George Philip, and Elliot van Kirk Dobbie, eds. The Exeter Book. The Anglo-Saxon Poetic Records 3. New York: Columbia University Press, 1936.

Krauss, F. A. Karl. Im Kerker vor und nach Christus: Schatten und Licht aus dem profanen und kirchlichen Cultur- und rechtsleben vergangener Zeiten. Freiburg: Mohr, 1895.

Lampert, Nicolas. "Haymarket: An Embattled History of Static Monuments and Public Interventions." In Art against the Law, edited by Rebecca Zorach, 47-58. Chicago: School of the Art Institute of Chicago, 2014.

Lang, James. "The Hogback: A Viking Colonial Monument." Anglo-Saxon Studies in Archaeology and History 3 (1984): 83-176.

Lantfred. Translatio et miracula S. Swithuni. In The Cult of St. Swithun, edited by Michael Lapidge, 217-334. Oxford: Clarendon Press, 2003.

Lees, Clare A. Tradition and Belief: Religious Writing in Late Anglo-Saxon England.

Minneapolis: University of Minnesota Press, 1999.

Lionarons, Joyce Tally. The Homiletic Writings of Archbishop Wulfstan. Cambridge: D. S. Brewer, 2010.

MacLean, Douglas. "King Oswald's Wooden Cross at Heavenfield in Context." In The Insular Tradition, edited by Robert T. Farrell, Catherine E. Karkov, and Michael Ryan, 79-97. Albany: State University of New York Press, 1997.

MacNeill, Eoin. "Ancient Irish Law. The Law of Status or Franchise." Proceedings of the Royal Irish Academy. Section C: Archaeology, Celtic Studies, History, Linguistics, Literature 36 (1921): 265-316.

Merback, Mitchell B. The Thief, the Cross, and the Wheel: Pain and the Spectacle of Punishment in Medieval and Renaissance Europe. Chicago: University of Chicago Press, 1998.

Neer, Richard T. The Emergence of the Classical Style in Greek Sculpture. Chicago: University of Chicago Press, 2010. 
O'Brien O'Keeffe, Katherine. Stealing Obedience: Narratives of Agency and Identity in Later Anglo-Saxon England. Toronto: University of Toronto Press, 2012.

Old English Poems of Christ and His Saints, edited and translated by Mary Clayton. Dumbarton Oaks Medieval Library 27. Cambridge, MA: Harvard University Press, 2013.

Peters, Edward M. "Prison before the Prison: The Ancient and Medieval Worlds." In The Oxford History of the Prison, edited by Norval Morris and David J. Rothman, 3-43. New York: Oxford University Press, 1995.

Pugh, R. B. Imprisonment in Medieval England. London: Cambridge University Press, 1968.

Rabanus Maurus. De universo libri viginti duo, edited by J. P. Migne. Patrologiae cusus completus; Series Latina 111. Paris: Migne, 1852.

Ramey, Peter. "The Riddle of Beauty: The Aesthetics of Wrætlic in Old English Verse." Modern Philology 114, no. 3 (2017): 457-81.

Rendall, Thomas. "Bondage and Freeing from Bondage in Old English Religious Poetry." Journal of English and Germanic Philology 73, no. 4 (1974): 497-512.

Rio, Alice. Slavery after Rome, 500-1100. Oxford: Oxford University Press, 2017.

Saltzman, Benjamin A. Bonds of Secrecy: Law, Spirituality, and the Literature of Concealment in Early Medieval England. Philadelphia: University of Pennsylvania Press, 2019.

The Saxon Mirror: A Sachsenspiegel of the Fourteenth Century, translated by Maria Dobozy. Philadelphia: University of Pennsylvania Press, 1999.

Sexton, Kim. "Justice Seen: Loggias and Ethnicity in Early Medieval Italy." Journal of the Society of Architectural Historians 68, no. 3 (2009): 309-37.

Summers, Joanna. Late-Medieval Prison Writing and the Politics of Autobiography. Oxford: Clarendon Press, 2004.

Szarmach, Paul E. “Another Old English Translation of Gregory the Great's Dialogues?” English Studies 62, no. 2 (1981): 97-109.

Szarmach, Paul E. "Boethius's Influence in Anglo-Saxon England: The Vernacular and the De consolation philosophiae." In A Companion to Boethius in the Middle Ages, edited by Noel Harold Kaylor and Philip Edward Phillips, 221-54. Leiden: Brill, 2012.

Szarmach, Paul E. "Three Versions of the Jonah Story: An Investigation of Narrative Technique in Old English Homilies." Anglo-Saxon England 1 (January 1972): 183-92.

Thomas, Daniel. "Incarceration as Judicial Punishment in Anglo-Saxon England." In Capital and Corporal Punishment in Anglo-Saxon England, edited by Jay Paul Gates and Nicole Marafioti, 92-112. Woodbridge, UK: Boydell \& Brewer, 2014.

Thomas, Daniel. "Rewriting Gregory the Great: The Prison Analogy in Napier Homily I." Review of English Studies 68, no. 284 (2017): 203-23.

Tilghman, Benjamin C. "On the Enigmatic Nature of Things in Anglo-Saxon Art." Different Visions, no. 4 (2014). differentvisions.org/on-the-enigmatic-nature-of-things-in-anglo-saxon -art/.

Verlinden, Charles. L'esclavage dans l'Europe médiévale. 2 vols. Brugge: De Tempel, 1955.

Webster, Leslie. "Visual Literacy in a Protoliterate Age." In Literacy in Medieval and Early Modern Scandinavian Culture, edited by Pernille Hermann, 21-46. Odense: University Press of Southern Denmark, 2005.

Williams, Howard. "Hogbacks: The Materiality of Solid Spaces.” In Early Medieval Stone Monuments: Materiality, Biography, Landscape, edited by Meggen Gondek, Joanne Kirton, and Howard Williams, 241-68. Woodbridge, UK: Boydell \& Brewer, 2015.

Winterbottom, Michael, ed. Three Lives of English Saints. Toronto: Published for the Centre for Medieval Studies by the Pontifical Institute of Mediaeval Studies, 1972. 